J. Clin. Chem. Clin. Biochem.

Vol. 27, 1989, pp. 531-537

(C) 1989 Walter de Gruyter \& Co.

Berlin - New York

\title{
Atrial Natriuretic Peptide Protects Hepatocytes Against Damage Induced by Hypoxia and Reactive Oxygen Possible Role of Intracellular Free Ionized Calcium
}

\author{
By A. A. von Ruecker, Maria Wild, G. S. Rao and F. Bidlingmaier \\ Institut für Klinische Biochemie, Universität Bonn, F.R.G.
}

(Received March 17/May 29, 1989)

Summary: Elevated concentrations of atrial natriuretic peptide reportedly mitigate acute renal failure in vivo and in the isolated perfused kidney (M. Nakamoto, J. I. Shapiro, P. F. Shanley, L. Chan \& R. W. Shrier (1987) J. Clin. Invest. 80, 698-705; S. G. Shaw, J. Weidmann, J. Hodler, A. Zimmermann \& A. Paternostro (1987) J. Clin. Invest. $80,1232-1237)$. Since atrial natriuretic peptide has been shown to be a potent vasodilator, this beneficial effect may be due entirely to improved haemodynamics. To determine whether atrial natriuretic peptide also has a protective effect at the cellular level, rat hepatocyte cell cultures were treated with atrial natriuretic peptide prior to or after induction of cell damage by hypoxia $\left(0.5 \% \mathrm{O}_{2}\right.$ for $\left.4 \mathrm{~h}\right)$ or reactive oxygen (hypochlorous acid). Bleb formation, degradation of radiolabeled trichloroacetic acid-precipitable peptides, release of lactate dehydrogenase and trypan blue exclusion were used as indicators of cell damage. Atrial natriuretic peptide treatment distinctly protected the cell cultures against damage in both cases. This beneficial effect of atrial natriuretic peptide was partly mimicked by sodium nitroprusside, which, like atrial natriuretic peptide, largely increased the cellular cGMP content. 6-Anilino-5,8-quinolinedione (Ly 83583), an inhibitor of particulate guanylate cyclase, blocked the protective effect of atrial natriuretic peptide. Therefore a cGMPmediated mechanism seems to be involved in the cytoprotective action of atrial natriuretic peptide. Fluorometric measurements using the $\mathrm{Ca}^{2+}$-sensitive dye Quin-2 showed that the elevation of intracellular $\mathrm{Ca}^{2+}$ after cellular insult by hypochlorous acid is prevented by atrial natriuretic peptide. These results suggest that atrial natriuretic peptide may attenuate hypoxic and toxic cell damage by increasing cGMP and reducing intracellular $\mathrm{Ca}^{2+}$.

\section{Introduction}

Atrial natriuretic peptide, a hormone secreted from specific granules of the mammalian atria $(1,2)$, exhibits several biological effects including vasorelaxation (3), natriuresis $(2,4)$, and inhibition of aldosterone-secretion (5). Atrial natriuretic peptide opposes the vascular smooth muscle contraction induced by e.g. angiotensin II, norepinephrine, histamine and serotonin $(6,7)$. Also, it has been shown that atrial natriuretic peptide binds to specific receptors in the vascular tissue (8). Therefore atrial natriuretic peptide may play an important physiological role in circulatory homeostasis and haemodynamics.
More recent reports have shown that elevated concentrations of atrial natriuretic peptide can mitigate post-ischaemic renal failure in vivo and in the isolated perfused kidney $(9,10)$. It is possible that this effect is mediated entirely by increased vasodilatation and improved haemodynamics. The following study examined whether atrial natriuretic peptide can also protect cells or cell cultures after exposure to hypoxia and reactive oxygen (via hypochlorous acid), procedures well known to induce cell damage similar to post-ischaemic injury in vivo. Rat hepatocytes were used, and these showed a considerable increase in cGMP content after atrial natriuretic peptide stimu- 
lation, suggesting the presence of atrial natriuretic peptide receptors. Cell damage in hepatocytes was assessed by the increased formation of membrane extrusions (blebs), the increased degradation of radiolabeled polypeptides, the release of lactate dehydrogenase and the uptake of trypan blue, as described previously $(11-13)$. Changes in intracellular free $\mathrm{Ca}^{2+}$, which may play a central role in toxic and ischaemic cell injury (14), were monitored using the $\mathrm{Ca}^{2+}$-sensitive fluorescent dye, Quin-2. Our study demonstrates that the beneficial effect of atrial natriuretic peptide observed after ischaemia and hypoxia in the kidney may also be due to protective effects of atrial natriuretic peptide at the cellular level.

\section{Materials and Methods}

Materials

Atrial natriuretic peptide, hypochlorous acid, sodium nitroprusside and Quin-2 (2-\{[2-bis-(carboxymethyl)-amino-5-methylphenoxy]-methyl\}-6-methoxy-8-bis-(carboxymethyl)-aminoquinoline) tetraacetoxymethyl ester were from Sigma Chemicals, Munich. Ham's F-12 medium, Hanks' balanced salt solution, Dulbecco's modified Eagle's medium and collagenase type II were from Seromed, Munich. All other solvents and chemicals were from Merck, Darmstadt. 6-Anilino-5,8-quinolinedione (Ly 83583) was a generous gift from Lilly Research Laboratories, Indianapolis, Ind.

\section{Cell cultures}

Hepatocytes were isolated from fed male Sprague-Dawley rats, weighing $150-200 \mathrm{~g}$, by in situ perfusion of collagenase essentially as described previously (12). Yields of $0.2-0.4 \cdot 10^{9}$ cells per liver with $85-95 \%$ viability as determined by trypan blue exclusion, were routinely obtained. The hepatocytes were plated at a density of $50000 / \mathrm{cm}^{2}$ in collagen-coated petri-perm dishes (Heraeus, Düsseldorf), containing Ham's F-12 medium with foetal calf serum (volume fraction 0.10 ) at $37^{\circ} \mathrm{C}$ in a humified atmosphere of 0.95 air and $0.05 \mathrm{CO}_{2}$ for $6 \mathrm{~h}$. After incubation of cells for $6 \mathrm{~h}$, the cells were washed with phosphate-buffered saline to remove the unattached dead cells. Ham's F-12 medium supplemented with foetal calf serum (volume fraction 0.05 ) was replaced and the cells were incubated for further $20 \mathrm{~h}$.

\section{Hypoxia experiments}

Experiments were initiated after the $20 \mathrm{~h}$-old plated cells had been washed with phosphate-buffered saline and incubated in Ham's F-12 medium supplemented with foetal calf serum (volume fraction 0.05 ) for $2 \mathrm{~h}$. The hepatocyte monolayers were divided into a $20 \%-\mathrm{O}_{2}$ and a $0.5 \%-\mathrm{O}_{2}$ (hypoxic) group. The $20 \%-\mathrm{O}_{2}$ group was placed in a standard incubator with 0.05 $\mathrm{CO}_{2}: 0.95$ air at $37^{\circ} \mathrm{C}$. The hypoxic group was incubated at $37^{\circ} \mathrm{C}$ in $0.005 \mathrm{O}_{2}: 0.05 \mathrm{CO}_{2}: 0.945 \mathrm{~N}_{2}$. An oxygen electrode (Yellow Springs Instruments) was immersed in the medium of a culture dish to monitor $\mathrm{O}_{2}$ concentration. Usually 80-90 min were required for equilibration of the $\mathrm{O}_{2}$ concentration in the medium with the desired gas phase concentration. During hypoxia, atrial natriuretic peptide and other drugs (in salinestock solutions equilibrated with the hypoxic gas) were added via an airlock. Viability of the cultured cells was assayed by trypan blue exclusion and release of lactate dehydrogenase, essentially as described by Rubin \& Farber (13). The amount of enzyme in the supernatant was defined as the percentage of total enzyme released after exposure of the cells to digitonin $(2 \mathrm{~g} / \mathrm{l})$ for $30 \mathrm{~min}$.

\section{Treatment of hepatocytes with HidiO}

In experiments with $\mathrm{HClO}$ the $20 \mathrm{~h}$-old plated cells were washed with a modified Krebs-Henseleit buffer containing dialysed bovine serum albumin $(20 \mathrm{~g} / \mathrm{l})$, glucose $(15 \mathrm{mmol} / \mathrm{l})$, Hepes $(20$ $\mathrm{mmol} / \mathrm{l}), \mathrm{pH} 7.4$ and incubated in the same buffer at $37^{\circ} \mathrm{C}$ under an atmosphere of $0.95 \mathrm{O}_{2}, 0.05 \mathrm{CO}_{2}$ for $2 \mathrm{~h}$ without further additions. The plated hepatocytes were then checked by microscopy and trypan blue exclusion to ensure viability. HClO $(0.1 \mathrm{mmol} / \mathrm{l})$ was added to intact cultures as indicated without further changes of the medium. Readjustment of the $\mathrm{pH}$ after addition of $\mathrm{HClO}$ was not necessary. Controls contained the appropriate solvents without $\mathrm{HClO}$. All assays were done in triplicate.

\section{cGMP/cAMP determinations}

Isolated hepatocytes $\left(1 \times 10^{9} / 1\right)$ were washed twice with $D u l$ becco's modified Eagle's medium and then preincubated in culture dishes for $15 \mathrm{~min}$ in Dulbecco's modified Eagle's medium containing $10 \mathrm{mmol} / \mathrm{l}$ Hepes (pH 7.3) and $0.5 \mathrm{mmol} / 1$ isobutylmethylxanthine at $37^{\circ} \mathrm{C}\left(0.05 \mathrm{CO}_{2}, 0.95\right.$ air $)$. Atrial natriuretic peptide and/or other drugs were added to the cells for various times as indicated. After rapid centrifugation, the medium was aspirated, and $0.75-1 \mathrm{ml}$ of ice-cold trichloroacetic acid $(60$ $\mathrm{g} / \mathrm{l})$ was added to the cells. The intracellular CGMP and cAMP content was then measured by commercially available radioimmunoassay kits (New England Nuclear, Dreieich) as described (15).

Bleb formation, proteolysis of cellular polypeptides

In some experiments cell damage was also assessed by determining the percentage increase of membrane blebs as described previously (11). The rate of intracellular proteolysis was measured by the method of Seglen et al. (16) as modified by von Ruecker et al. (12).

\section{Measurement of cytosolic free $\mathrm{Ca}^{2+}$ concentration}

Isolated hepatocytes were incubated with Quin-2 tetraacetoxymethyl ester (Quin-2/AM) essentially as described by Nicchitta et al. (17). Briefly, cells were incubated at a concentration of $3 \times 10^{9} / 1$ in modified Hank's medium supplemented with $20 \mathrm{~g} / 1$ dialysed bovine serum albumin, and Quin-2/AM was added to a final concentration of $50 \mu \mathrm{mol} / 1$. After loading of bepatocytes for $15 \mathrm{~min}$, the cells were washed twice in modified Hank's buffer, containing $1 \mathrm{mmol} / 1 \mathrm{CaCl}_{2}$ and $1 \mathrm{mmol} / 1 \mathrm{MgCl}_{2}$. The cells were then resuspended in the same buffer at a cell concentration of $1 \times 10^{9} / 1$, and the fluorescence was recorded before and after $\mathrm{HClO}$-treatment in a Perkin Elmer LS-5 spectrofluorometer. The excitation wavelength was $339 \mathrm{~nm}$ and the emission was recorded at $500 \mathrm{~nm}$ using a cutoff filter. The cuvette chamber was kept at $37^{\circ} \mathrm{C}$ and the cells were continuously stirred under an atmosphere of $0.95 \mathrm{O}_{2}, 0.05 \mathrm{CO}_{2}$. Values for intracellular free $\mathrm{Ca}^{2+}$ were estimated by the method of Tsien et al. (18). 


\section{Results and Discussion}

Effect of atrial natriuretic peptide and different drugs on cGMP/cAMP accumulation in hepatocytes

The increase in cellular cGMP content at different atrial natriuretic peptide concentrations in hepatocytes is shown in figure 1. At optimal concentrations ( $\geq 0.1 \mu \mathrm{mol} / \mathrm{l})$, atrial natriuretic peptide caused a 1215 -fold increase in cellular cGMP. Table 1 shows that atrial natriuretic peptide did not alter the cellular cAMP content of hepatocytes, in contrast to the effect observed by others in cardiocytes (19). Sodium nitro-

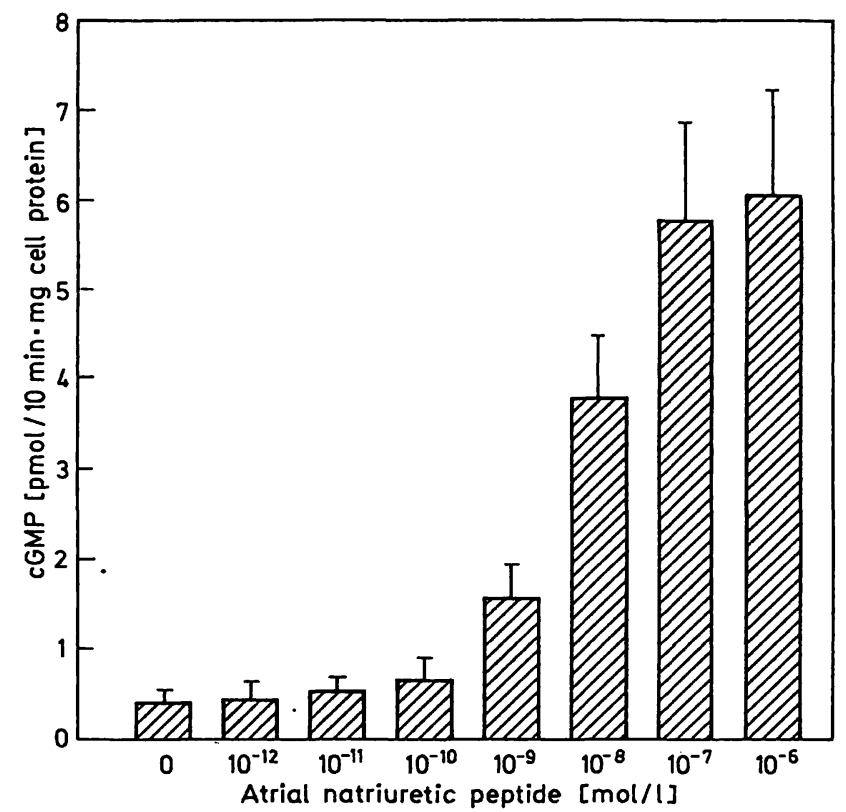

Fig. 1. Cyclic-GMP production of hepatocytes in response to increasing concentrations of atrial natriuretic peptide. Hepatocytes were prepared and incubated at $37^{\circ} \mathrm{C}$ for $10 \mathrm{~min}$ in the absence and presence of atrial natriuretic peptide as described in Methods. The cGMP levels in the cells were measured by radioimmunoassay (15). Values represent the mean \pm S. E. of 5 separate experiments, each performed in triplicate.

$0=$ without atrial natriuretic peptide prusside $(10 \mu \mathrm{mol} / \mathrm{l})$ also strongly increased the cellular cGMP content without changing cellular cAMP concentrations. The effects of atrial natriuretic peptide and nitroprusside on cellular cGMP were nearly additive (tab. 1). This confirms observations in rat lung fibroblasts made by Leitman et al. (15), who suggested that atrial natriuretic peptide and nitroprusside increase different pools of cGMP by activating different isoenzyme forms of guanylate cyclase. The drug 6-anilino-5,8-quinolinedione (Ly 83583), which interferes with the activation of the particulate guanylate cyclase (20), completely abolished the atrial natriuretic peptide-induced increase in cellular cGMP (tab. 1). These results suggest that hepatocytes possess receptors for atrial natriuretic peptide, and that the binding of atrial natriuretic peptide to the receptor on the hepatocyte membrane stimulates the particulate guanylate cyclase. Others have reported (21) that atrial natriuretic peptide activates the guanylate cyclase in particulate fractions from homogenates of rat liver.

Protective effect of atrial natriuretic peptide on hepatocyte monolayers exposed to hypoxia and reoxygenation

Hepatocyte monolayers were exposed to $0.5 \%$ oxygen for $4 \mathrm{~h}$; this low oxygen concentration has been shown to cause hypoxic injury in hepatocytes after reoxygenation (22). Figure 2 shows that with no reoxygenation period after hypoxia, the cells remained viable as judged by trypan blue exclusion. Also, the release of lactate dehydrogenase from the hypoxic cells into the supernatant was not notably increased compared with controls (fig. 2b). Atrial natriuretic peptide $(1 \mu \mathrm{mol} / \mathrm{l})$, given at the indicated intervals during hypoxia, and the inhibitor von 6-anilino-5,8-quinolinedione (Ly 83583$)(10 \mu \mathrm{mol} / \mathrm{l})$ did not change the outcome of the $0 \mathrm{~h}$-reoxygenation experiment. On the other hand, if the cells were exposed to prolonged

Tab. 1. Effect of atrial natriuretic peptide and different drugs on cGMP/cAMP accumulation in hepatocytes

\begin{tabular}{lrr}
\hline Addition & $\begin{array}{c}\text { cGMP } \\
\text { (pmol/mg cell protein) }\end{array}$ & $\begin{array}{r}\text { cAMP } \\
\text { (pmol/mg cell protein) }\end{array}$ \\
\hline Control & $0.43 \pm 0.12$ & $94 \pm 18$ \\
Atrial natriuretic peptide $(1 \mu \mathrm{mol} / \mathrm{l})$ & $6.07 \pm 1.54$ & $97 \pm 15$ \\
Nitroprusside $(10 \mu \mathrm{mol} / \mathrm{l})$ & $18.91 \pm 1.61$ & $91 \pm 19$ \\
Nitroprusside $(10 \mu \mathrm{mol} / \mathrm{l})+$ atrial natriuretic peptide $(0.1 \mu \mathrm{mol} / \mathrm{l})$ & $23.42 \pm 1.97$ & $101 \pm 12$ \\
Atrial natriuretic peptide $(0.1 \mu \mathrm{mol} / \mathrm{l})$ & $0.37 \pm 0.10$ & $\mathrm{n} . \mathrm{d}$. \\
$\quad+$ 6-anilino-5,8-quinolinedione (Ly 83583$)(10 \mu \mathrm{mol} / \mathrm{l})$ & & \\
\hline
\end{tabular}

Isolated hepatocytes were incubated at $37^{\circ} \mathrm{C}$ for $10 \mathrm{~min}$ in the presence of either atrial natriuretic peptide, sodium nitroprusside or the combination of both agents, as described in Methods. 6-Anilino-5,8-quinolinedione (Ly 83583) was added 5 min prior to addition of atrial natriuretic peptide. The intracellular cGMP and cAMP levels were measured by radioimmunoassay as described (15). Each value represents the mean \pm S.E. from 7 different experiments performed in triplicate. 


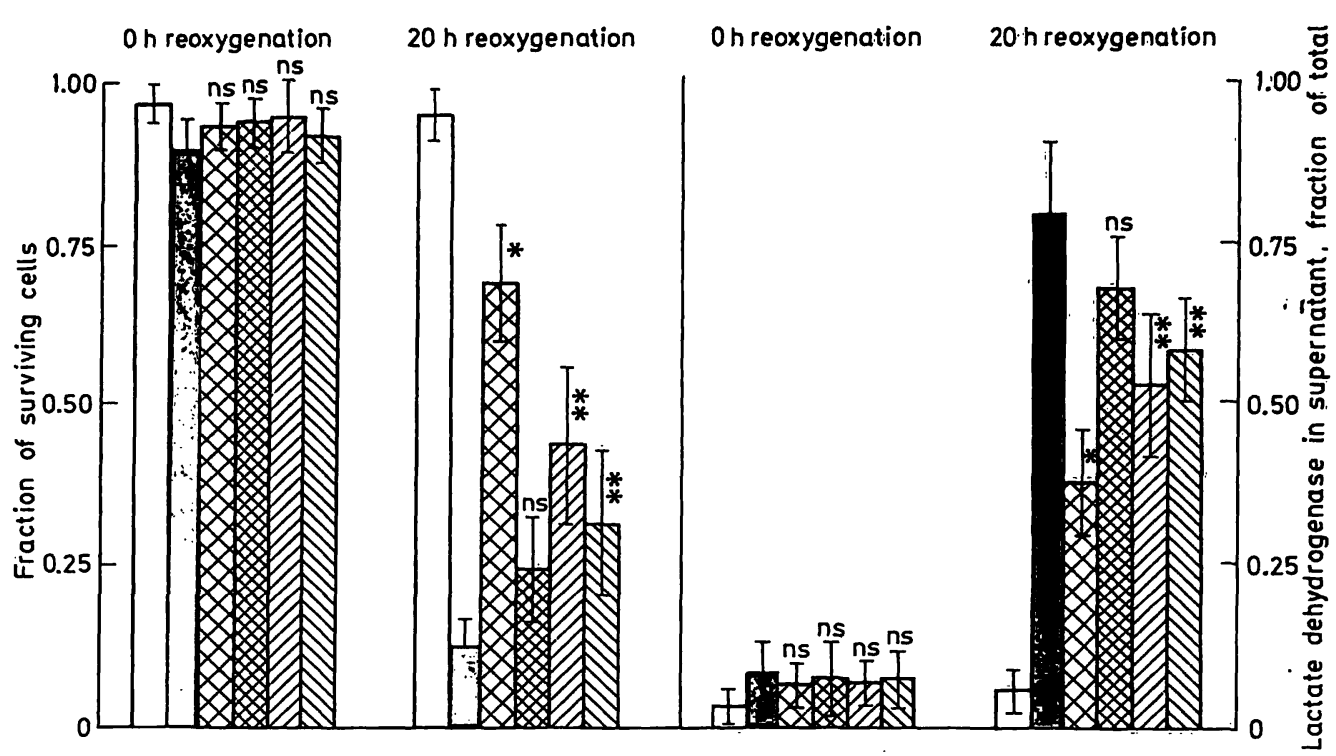

Fig. 2. Cytoprotective action of atrial natriuretic peptide after hypoxia and reoxygenation in cultured hepatocytes. Hepatocyte cell cultures were exposed to hypoxia $\left(0.5 \% \mathrm{O}_{2}\right)$ for $4 \mathrm{~h}$ and reoxygenation $\left(20 \% \mathrm{O}_{2}\right)$ for 0 and $20 \mathrm{~h}$ as described in Methods. Atrial natriuretic peptide $(1 \mu \mathrm{mol} / \mathrm{l})$ was added to the cell cultures immediately prior to hypoxia, after $2 \mathrm{~h}$ of hypoxia (via airlock) and at the end of hypoxia as indicated below. 6-Anilino-5,8-quinolinedione (Ly 83583$)(10 \mu \mathrm{mol} / \mathrm{l})$ was added to the culture medium 1-2 min before atrial natriuretic peptide.

a) Cell survival assessed by trypan blue exclusion, and

b) Cell lysis assessed by release of lactate dehydrogenase into the supernatant.

Normoxic controls with drug additions did not differ from controls without drugs. Values are the mean \pm S.E. of 3 separate experiments, each performed in triplicate.

$\square$ control;
$\square$ hypoxia $4 \mathrm{~h}$ without additions;

hypoxia $4 \mathrm{~h}$ in the presence of atrial natriuretic peptide;

hypoxia $4 \mathrm{~h}$ in the presence of atrial natriuretic peptide and 6-anilino-5,8-quinolinedione (Ly 83583);

VI77 hypoxia $4 \mathrm{~h}$; atrial natriuretic peptide added after $2 \mathrm{~h}$;

WWV hypoxia $4 \mathrm{~h}$; atrial natriuretic peptide added after $4 \mathrm{~h}$.

${ }^{*} \mathrm{p}<0.01 ;{ }^{* *} \mathrm{p}<0.05 ; \mathrm{ns}=$ not significant (in comparison with $4 \mathrm{~h}$ hypoxia treatment without additions).

$20 \mathrm{~h}$ reoxygenation, the survival rate was low (trypan blue exclusion was observed in less than $15 \%$ of the cells) and most cells were lysed as judged by the release of lactate dehydrogenase (fig. $2 a$ and $2 b$ ). Atrial natriuretic peptide treatment, given before, during or after hypoxia, distinctly increased the survival rate and lessened cell lysis; atrial natriuretic peptide was most effective when added before hypoxia, and the beneficial effect was notably less when atrial natriuretic peptide was given after a 2 or $4 \mathrm{~h}$ hypoxia period. 6-Anilino-5,8-quinolinedione (Ly 83583), which suppressed the atrial natriuretic peptide-mediated formation of cGMP (tab. 1), greatly diminished the cytoprotective effect of atrial natriuretic peptide (fig. 2). Therefore, a cGMP-dependent mechanism seems to be involved in atrial natriuretic peptideinduced cytoprotection.

In these experiments detectable damage to the cells occurred after the physiological oxygen concentration had been restored, rather than during the hypoxic period itself. This so-called 'reoxygenation effect' after hypoxia has been observed by several authors in various tissues (for review see 1.c. (23)), and it has been attributed to increased lipid peroxidation, by the reactive oxygen that is formed after reoxygenation. Similar reoxygenation effects in hepatocytes exposed to hypoxia have been observed by Costa et al. (22). Nevertheless, since atrial natriuretic peptide was more beneficial when it was added earlier during hypoxia (fig. 2), some irreversible detrimental events, even though not detectable by the methods employed, seem to occur during hypoxia.

Protective effect of atrial natriuretic peptide after treatment of hepatocyte monolayers with hypochlorous acid

Hypochlorous acid forms reactive oxygen when exposed to diffuse daylight ( $\mathrm{HClO} \rightarrow \mathrm{O}+\mathrm{HCl}$ ). In order to study the effects of reactive oxygen, which is known to adversely influence tissues during reoxygenation (23), we decided to apply $\mathrm{HClO}$ to hepato- 


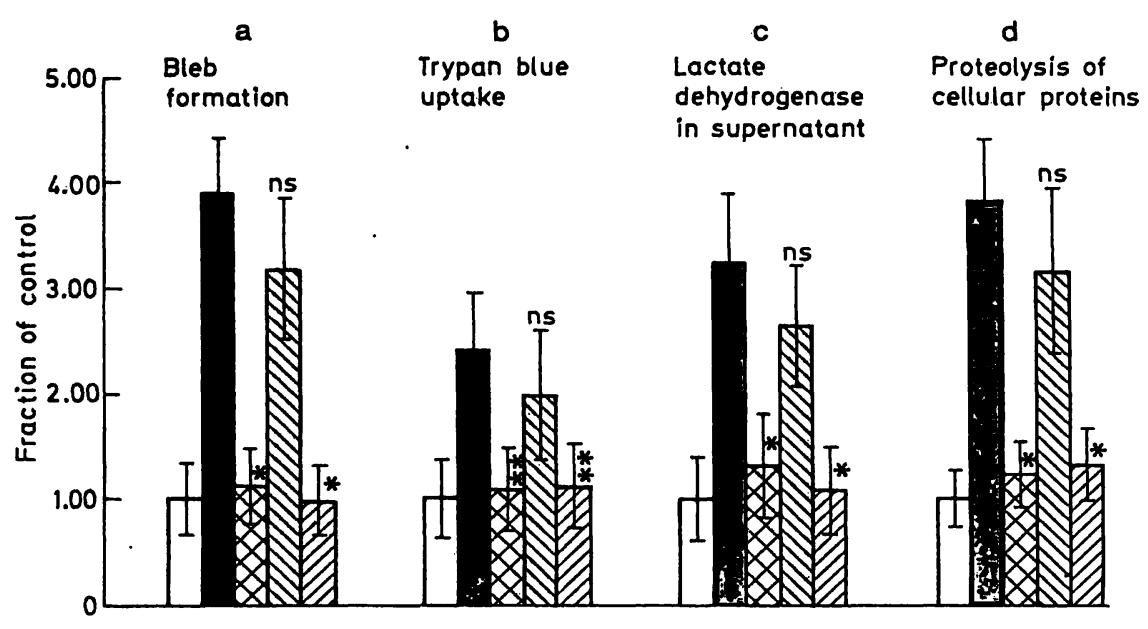

Fig. 3. Protection of cultured hepatocytes against HClO-induced cell damage by atrial natriuretic peptide. Hepatocyte cell cultures were exposed to $\mathrm{HClO}(0.1 \mathrm{mmol} / \mathrm{l})$ for $30 \mathrm{~min}$ in the absence and presence of atrial natriuretic peptide $(1 \mu \mathrm{mol} / \mathrm{l})$, sodium nitroprusside $(10 \mu \mathrm{mol} / \mathrm{l})$ and 6-anilino-5,8-quinolinedione (Ly 83583) $(10 \mu \mathrm{mol} / \mathrm{l})$ as indicated below. The drugs or combination of drugs were added $5 \mathrm{~min}$ prior to $\mathrm{HClO}$. Cell damage was assessed (see Methods) by

a) bleb formation (control: $5.2 \%$ of $3 \times 500$ cells with blebs),

b) trypan blue uptake (control: $2,7 \%$ of $3 \times 500$ cells with dye uptake),

c) lactate dehydrogenase in supernatant (control: $1.8 \%$ of maximal release in supernatant),

d) proteolysis of $\left[{ }^{14} \mathrm{C}\right]$ valine-labeled cellular proteins (control: $3.1 \%$ of $\left[{ }^{14} \mathrm{C}\right]$ valine-incorporation was trichloroacetic acidsoluble).

Control experiments done in the absence of $\mathrm{HClO}$ but in the presence of atrial natriuretic peptide, sodium nitroprusside and 6-anilino-5,8-quinolinedione (Ly 83583) did not significantly differ from normal control experiments without drugs. Values are the mean $\pm \mathrm{S}$. E. of 3 separate experiments, each performed in triplicate.

$\square$ control cells;

cells treated with $\mathrm{HClO}$

18 cells treated with $\mathrm{HClO}$ in the presence of atrial natriuretic peptide;

DWW cells treated with $\mathrm{HClO}$ in the presence of atrial natriuretic peptide and 6-anilino-5,8-quinolinedione (Ly 83583); D7Z cells treated with $\mathrm{HClO}$ in the presence of $\mathrm{Na}^{+}$nitroprusside.

${ }^{*} \mathrm{p}<0.01 ;{ }^{* *} \mathrm{p}<0.05 ; \mathrm{ns}=$ not significant (in comparison with cells treated with $\mathrm{HClO}$ ).

cyte monolayers. Again atrial natriuretic peptide was used in HClO-treated monolayers to determine its potential as a cytoprotective agent. Nitroprusside, which like atrial natriuretic peptide, increased the cellular cGMP content of hepatocytes (but via soluble guanylate cyclase) (tab. 1), was also tested. Figure 3 shows that all indicators of the onset of cell damage (i.e. bleb formation, trypan blue uptake, release of lactate dehydrogenase, increase in proteolysis) were distinctly increased if the cells were treated with $\mathrm{HClO}$ $(0.1 \mathrm{mmol} / \mathrm{l})$ for $30 \mathrm{~min}$ at $37^{\circ} \mathrm{C}$. Pretreatment of cells with atrial natriuretic peptide $(1 \mu \mathrm{mol} / \mathrm{l})$ or nitroprusside $(10 \mu \mathrm{mol} / \mathrm{l})$ nearly abolished the cell-damaging effects of $\mathrm{HClO}(0.1 \mathrm{mmol} / \mathrm{l})$. 6-Anilino-5,8quinolinedione (Ly 83583$)(10 \mu \mathrm{mol} / \mathrm{l})$, which blocks atrial natriuretic peptide-induced activation of the particulate guanylate cyclase, largely inhibited the protective action of atrial natriuretic peptide (fig. 3). Controls done in the presence of these drugs but without HClO did not differ from normal controls (data not shown). These observations suggest that, as in the case of hypoxic cell injury (fig. 2), atrial natri- uretic peptide also induces cytoprotective action after cellular insult by $\mathrm{HClO}$ (or reactive oxygen). A cGMP-dependent mechanism seems to be involved.

Increase of intracellular $\mathrm{Ca}^{2+}$ following cell damage by hypochlorous acid and its prevention by atrial natriuretic peptide and sodium nitroprusside

Various authors stress that alterations in cellular $\mathrm{Ca}^{2+}$ homeostasis may be the critical event in hypoxic and reactive oxygen-induced cell injury (for review see 1 . c. (14)). Since smooth muscle cells have been shown to loose $\mathrm{Ca}^{2+}$ as a consequence of cGMP accumulation (24) and atrial natriuretic peptide treatment (25), we examined whether atrial natriuretic peptide and nitroprusside influence the intracellular free $\mathrm{Ca}^{2+}$ concentration of hepatocytes following exposure to $\mathrm{HClO}$. Figure 4 shows that a slow but distinct increase in cytosolic free $\mathrm{Ca}^{2+}$ occurred in $\mathrm{HClO}$-treated hepatocytes for at least $10 \mathrm{~min}$. This increase in intracell- 
ular $\mathrm{Ca}^{2+}$ was inhibited by atrial natriuretic peptide (fig. 4) and nitroprusside (data not shown) in a similar fashion. 6-Anilino-5,8-quinolinedione (Ly 83583) blocked the action of atrial natriuretic peptide on intracellular $\mathrm{Ca}^{2+}$. In the absence of $\mathrm{HClO}$, atrial natriuretic peptide and nitroprusside caused only a small decrease $(<10 \%)$ of cytosolic $\mathrm{Ca}^{2+}$ during the observation period. These findings lead us to propose

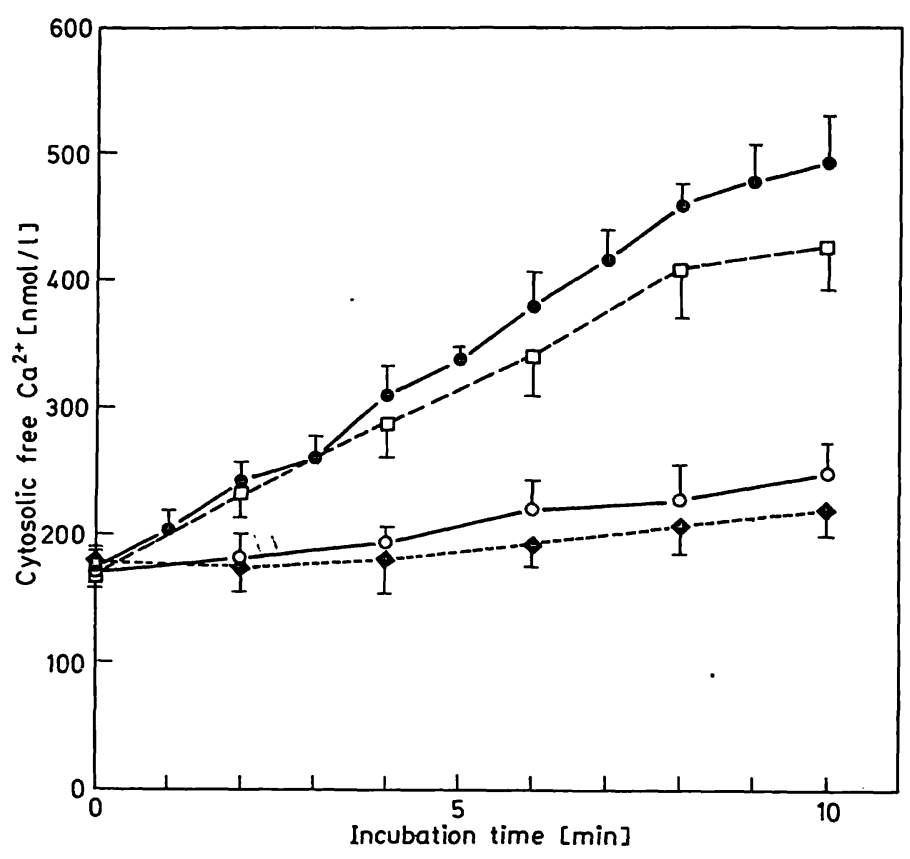

Fig. 4. Inhibition of HClO-induced increase in cytosolic free $\mathrm{Ca}^{2+}$ in hepatocytes by atrial natriuretic peptide. Isolated hepatocytes were loaded with Quin-2 and incubated at $37^{\circ} \mathrm{C}$ in an spectrofluorometer as described in Methods. Fluorescence was measured once or twice per min. After stabilization of the Quin-2 signal (approx. $2 \mathrm{~min}$ ), a solvent with or without atrial natriuretic peptide $(1 \mu \mathrm{mol} / \mathrm{l})$ was added $1 \mathrm{~min}$ prior to the addition of $\mathrm{HClO}(0.1 \mathrm{mmol} / \mathrm{l})$. Cytosolic $\mathrm{Ca}^{2+}$ levels were determined as described by Tsien et al. (18). Each point represents the mean $\pm \mathrm{S}$. E. of 4 experiments.

$\diamond-\cdots$ : control cells

$\longrightarrow$ : cells treated with $\mathrm{HClO}$;

$\mathrm{O}-\mathrm{O}$ : cells treated with $\mathrm{HClO}$ in the presence of atrial natriuretic peptide;

$\square--\square \quad$ : cells treated with $\mathrm{HClO}$ in the presence of atrial natriuretic peptide + 6-anilino-5,8quinolinedione (Ly 83583) that atrial natriuretic peptide and nitroprusside protect hepatocytes against $\mathrm{HClO}$-induced cell injury by preventing the post-injury increases of intracellular $\mathrm{Ca}^{2+}$.

\section{Concluding Remarks}

Our results show that atrial natriuretic peptide can protect hepatocytes after hypoxic and toxic $(\mathrm{HClO})$ insult. The beneficial effects of elevated atrial natriuretic peptide concentrations observed in acute ischaemic renal failure (9) and in the isolated perfused kidney (10) may therefore not only be due to atrial natriuretic peptide-induced vasodilatation and improved haemodynamics, but also to atrial natriuretic peptide-induced protection at the cellular level. The cytoprotective actions of atrial natriuretic peptide were mimicked in our experiments by nitroprusside, which, like atrial natriuretic peptide, increases the cGMP content in the cell. 6-Anilino-5,8-quinolinedione ( $L y$ 83583), which inhibits activation of the particulate guanylate cyclase by atrial natriuretic peptide, largely blocked the protective effect of atrial natriuretic peptide. Therefore the formation of cGMP and cGMP-dependent mechanisms seem important for cytoprotection by atrial natriuretic peptide. Since $\mathrm{HClO}$-induced cell injury and the accompanying increase in intracellular $\mathrm{Ca}^{2+}$ were simultaneously prevented by atrial natriuretic peptide, it is reasonable to assume that the cytoprotective effects of atrial natriuretic peptide are mediated by systems involved in the maintenance of cellular $\mathrm{Ca}^{2+}$ balance. Via cGMP-dependent mechanisms, atrial natriuretic peptide may be involved in the modulation of the gating of voltage-dependent $\mathrm{Ca}^{2+}$ channels (26), or in the modulation of the $\mathrm{Ca}^{2+}$-pumping ATPase and the $\mathrm{Na}^{+} / \mathrm{Ca}^{2+}$ exchange system present in the cell membrane $(27,28)$. The exact mechanism of atrial natriuretic peptide remains to be elucidated.

\section{Acknowledgement}

We are grateful to Dr. G. Wild for valuable help and discussions.

4. Garcia, R., Cantin, M., Thibault, G., Ong, H. \& Genest, J. (1982) Relationship of specific granules to the natriuretic and diuretic activity of rat atria. Experientia 38, 10711077.

5. Goodfriend, R., Elliot, M. E. \& Atlas, S. A. (1984) Actions of synthetic atrial natriuretic factor on bovine adrenal glomerulosa. Life Sci. 34, 992-998.

6. Garcia, R., Thibault, G., Cantin, M. \& Genest, J. (1984) Effect of a purified atrial natriuretic factor on rat and rabbit vascular strips and vascular beds. Am. J. Physiol. 247, R34-39. 
7. Takuwa, T. \& Rasmussen, H. (1987) Measurement of cytoplasmic free $\mathrm{Ca}^{2+}$ concentration in rabbit aorta using the photoprotein, aequorin. J. Clin. Invest. 80, 248-257.

8. Hirata, Y., Tomita, M., Yoshimi, H. \& Ikeda, M. (1984) Specific receptors for atrial natriuretic factor (ANF) in cultured vascular smooth muscle cells of rat aorta. Biochem. Biophys. Res. Commun. 125, 562-568.

9. Shaw, S. G., Weidmann, J., Hodler, J., Zimmermann, A. \& Paternostro, A. (1987) Atrial natriuretic peptide protects against acute ischemic renal failure in the rat. J. Clin. Invest. $80,1232-1237$.

10. Nakamoto, M., Shapiro, J. I., Shanley, P. F., Chan, L. \& Shrier, R. W. (1987) In vitro and in vivo protective effect of atriopeptin III on ischemic acute renal failure. J. Clin. Invest. 80, 698-705.

11. Rao, G. S., Lemoch, H., Kessler, H., Damm, I., Eiermann, V., Koll, S., Zarbock, J. \& Usadel, K. H. (1986) Prevention of phalloidin-induced lesions on isolated rat hepatocytes by novel synthetic analogues of somatostatin. Klin. Wochenschr. 64, (Suppl. VII) 79-86.

12. von Ruecker, A. A., Rao, G. S. \& Bidlingmaier, F. (1988) Cyclosporin A inhibits proteolytic cleavage and degradation of membrane-bound protein kinase $C$ in hepatocytes after stimulation by phorbol ester. Biochem. Biophys. Res. Commun. 151, 997-1003.

13. Rubin, R. \& Farber, J. L. (1984) Mechanisms of the killing of cultured hepatocytes by hydrogen peroxide. Arch. Biocbem. Biophys. 228, 450-459.

14. Cheung, J. Y. Bonventre, J. V., Malis, C. D. \& Leaf, A. (1986) Calcium and ischemic injury. N. Engl. J. Med. 314, 1670-1676.

15. Leitman, D. C., Agnost, V. L., Tuan, J. J., Andresen, J. W. \& Murad, F. (1987) Atrial natriuretic factor and sodium nitroprusside increase cyclic GMP in cultured rat lung fibroblasts by activating different forms of guanylate cyclase. Biochem. J. 244, 69-74.

16. Seglen, P. O., Grinde, B. \& Solheim, A. E. (1979) Inhibition of the lysosomal pathway of protein degradation in isolated rat hepatocytes by ammonia, chloroquine and leupeptin. Eur. J. Biochem. 144, 19-23.

17. Nicchitta, C. V., Kamoun, M. \& Williamson, J. R. (1985) Cyclosporine augments receptor-mediated cellular $\mathrm{Ca}^{2+}$ fluxes in isolated hepatocytes. J. Biol. Chem. 260, 1361313618.
18. Tsien, R. Y., Pozzan, T. \& Rink, T. J. (1982) Measuring and manipulating cytosolic $\mathrm{Ca}^{2+}$ with trapped indicators. J. Cell Biol. 94, 325-334.

19. Anand-Srivastava, M. B. \& Cantin, M. (1986) Atrial natriuretic factor receptors are negatively coupled to adenylate cyclase in cultured atrial and ventricular cardiocytes. Biochem. Biophys. Res. Commun. 138, 427-436.

20. O'Donnell, M. E. \& Owen, N. E. (1986) Role of cyclic GMP in atrial natriuretic factor stimulation of $\mathrm{Na}^{+}, \mathrm{K}^{+}$, $\mathrm{Cl}^{-}$cotransport in vascular smooth muscle cells. J. Biol. Chem. 261, $15461-15466$.

21. Waldman, S. A., Rapoport, R. M. \& Murad, F. (1984) Atrial natriurctic factor selectively activates particulate guanylate cyclase and elevates cyclic GMP in rat tissues. J. Biol. Chem. 259, $14332-14334$.

22. Costa, A. K., Heffel, D. F., Schieble, T. M. \& Trudell, J. R. (1987) Toxicity of $t$-butylhydroperoxide in hepatocyte monolayers exposed to hypoxia and reoxygenation. In Vitro Cell. Develop. Biol. 23, 501-506.

23. McCord, J. M. (1985) Oxygen-derived free radicals in postischemic tissue injury. N. Engl. J. Med. 312, 159-163.

24. Murad, F. (1986) Cyclic guanosine monophosphate as a mediator of vasodilation. J. Clin. Invest. $78,1-5$.

25. Meyer-Lehnert, H., Tsai, P. \& Schrier, R. W. (1987) Atrial natriuretic factor (ANF) inhibits Arginine vasopressinstimulated $\mathrm{Ca}^{2+}$ fluxes and cell contraction in vascular smooth muscle cells. Klin. Wochenschr. 65, (Suppl. VIII) 115-121.

26. Richards, I. S., Murlas, C., Ousterhout, J. M. \& Sperelakis, N. (1986) Modulation of the gating of voltage-dependent and of receptor-operated $\mathrm{Ca}^{2+}$ channels by cGMP. Eur. J. Pharmacol. 128, 229-302.

27. Kobayashi, S., Kanaide, H. \& Nakamura, M. (1985) Cytosolic-free $\mathrm{Ca}^{2+}$ transients in cultured vascular smooth muscle cells: microfluorometric measurements. Science 229, $553-556$.

28. Baltensperger, K., Carafoli, E. \& Chiesi, M. (1988) The $\mathrm{Ca}^{2+}$-pumping ATPase and the major substrates of the cGMP-dependent protein kinase in smooth muscle sarcolemma are distinct entities. Eur. J. Biochem. 172, 7-16.

Dr. Alexander von Ruecker/

Prof. Dr. Frank Bidlingmaier

Department of Clinical Biochemistry

University of Bonn

Sigmund-Freud-Straße 25

D-5300 Bonn 1 
